\title{
Polymerization of $\varepsilon$-caprolactone using ruthenium(II) mixed metallocene catalysts and isopropyl alcohol: Living character and mechanistic study
}

\author{
Andreia Valente ${ }^{\mathrm{a}, \mathrm{b}, \mathrm{c}, \mathrm{d}, \mathrm{e}}$, Philippe Zinck ${ }^{\mathrm{a}, \mathrm{b}, \mathrm{c}, \mathrm{d}}$, André Mortreux ${ }^{\mathrm{a}, \mathrm{b}, \mathrm{c}, \mathrm{d}}$, Marc Visseaux ${ }^{\mathrm{a}, \mathrm{b}, \mathrm{c}, \mathrm{d}}$, \\ Paulo J.G. Mendes ${ }^{\mathrm{f}}$, Tiago J.L. Silva ${ }^{\mathrm{e}, \mathrm{f}}$, M. Helena Garcia ${ }^{\mathrm{e}, *}$ \\ a Univ Lille Nord de France, F-59000 Lille, France \\ ${ }^{\mathrm{b}}$ ENSCL, UCCS, CCM, F-59652 Villeneuve d'Ascq, France \\ ' USTL, UCCS, CCM, F-59655 Villeneuve d'Ascq, France \\ d CNRS, UMR8181, F-59652 Villeneuve d'Ascq, France \\ e Centro de Ciências Moleculares e Materiais, Departamento de Química e Bioquímica, Faculdade de Ciências da Universidade de Lisboa, Campo Grande, 1749-016, Lisboa, Portugal \\ ${ }^{\mathrm{f}}$ Centro de Química de Évora, Departamento de Química da Escola de Ciências e Tecnologia da Universidade de Évora, Rua Romão Ramalho 59, 7002-554 Évora, Portugal
}

\section{A R T I C L E I N F O}

\section{Article history:}

Received 28 April 2011

Received in revised form 28 June 2011

Accepted 30 June 2011

Available online 6 July 2011

\section{Keywords:}

$\varepsilon$-Caprolactone polymerization ROP

Activated Monomer mechanism

Mixed sandwich

Ruthenium(II) complexes

Density Functional Theory

\begin{abstract}
A B S T R A C T
A series of ruthenium(II) complexes with the general formula $\left[\mathrm{Ru}\left(\eta^{5}-\mathrm{C}_{5} \mathrm{H}_{5}\right)\left(\eta^{6}\right.\right.$-substituted arene) $]^{+}\left[\mathrm{PF}_{6}\right]^{-}$(substituted arene $=2$-phenylpyridine $(\mathbf{1})$, dibenzosuberone $(\mathbf{2})$ and toluene $(\mathbf{3})$ ), in combination with isopropyl alcohol were used for the polymerization of $\varepsilon$-caprolactone. The polymerization was found to be quantitative and controlled, with PDI in the range 1.1-1.3. By means of MALDI-ToF analyses, functionalization studies with D,L-lactide and NMR monitoring techniques, it has been found that the polymerization proceeds via a living Activated Monomer mechanism (AM) involving an $\eta^{6}-\eta^{4}$ change of the coordination mode of the arene. These experimental results were corroborated by DFT studies. The growth of several polymer chains per ruthenium atom highlights interesting potentialities for molecular weight control and catalyst economy. The stability of the ruthenium complexes allows their recovery at the end of the polymerization, which can be viewed as a further advance in a green chemistry frame.
\end{abstract}

(c) 2011 Elsevier B.V. All rights reserved. 